\title{
Correction to: Predation rate linked to life table of Chrysoperla carnea (Stephen) \\ (Neuroptera: Chrysopidae) fed on small walnut aphid (Chromaphis juglandicola) (Kalt.) (Hemiptera: Aphididae): with population and predation projections
}

\author{
Mehmet Yılmaz • Evin Polat Akköprü \\ Published online: 24 July 2021 \\ (C) Springer Nature B.V. 2021
}

\section{Correction to: Phytoparasitica}

https://doi.org/10.1007/s12600-020-00834-3

The original version of this article unfortunately contained a mistake in the Table 2 and in the body text, the lambda symbol $(\kappa)$ can be seen in html format of Table 2 but was not presented in the pdf.
The original article can be found online at https://doi.org/10.1007 /s12600-020-00834-3

M. Yılmaz • E. P. Akköprü $(\bowtie)$

Department of Plant Protection, Faculty of Agriculture, University of Van Yuzuncu Y11, 65080 Van, Turkey

e-mail: polatevin@gmail.com.tr
The corrected Table 2 is shown below.

Table 2 Reproduction and population parameters of C. carnea fed with C. juglandicola

\begin{tabular}{lc}
\hline Parameters & C. carnea \\
\hline Fecundity (eggs/female) & $257.7 \pm 11.78$ \\
(APOP) (d) & $8.00 \pm 0.6746$ \\
(TPOP) (d) & $33.00 \pm 0.650$ \\
Oviposition days & $43.37 \pm 1.640$ \\
$r\left(d^{-1}\right)$ & $0.072 \pm 0.007$ \\
$\left.\kappa \mathrm{d}^{-1}\right)$ & $1.075 \pm 0.007$ \\
$R_{0}($ offspring) & $62.48 \pm 19.42$ \\
$T(\mathrm{~d})$ & $57.16 \pm 1.152$ \\
\hline
\end{tabular}

Standard errors were estimated by using the bootstraps technique with 100,000 resampling

Publisher's note Springer Nature remains neutral with regard to jurisdictional claims in published maps and institutional affiliations. 